\title{
Reaction of soybean genotypes to foliar diseases with and without fungicide application
}

\section{Reação de genótipos de soja a doenças foliares com e sem aplicação de fungicida}

\author{
Rânia Nunes OLIVEIRA MORAES ${ }^{1}$; Gustavo André SIMON²; Hercules Diniz CAMPOS; \\ Renata Cristina ALVARES ${ }^{4}$
}

${ }^{1}$ Autor para correspondência, Mestranda, Universidade de Rio Verde, Fazenda Fontes do Saber, Caixa Postal 104, CEP:
75901-970, Rio Verde, Goiás. E-mail: rania_agro@hotmail.com
${ }^{2}$ Doutor, Universidade de Rio Verde. E-mail: simon@unirv.edu.br
${ }^{3}$ Doutor, Universidade de Rio Verde. E-mail: camposhd@brturbo.com.br
${ }^{4}$ Doutora, Caraíba Genética. Email: renata.alvares@caraibagenetica.com.br

Recebido em: 08-11-2017; Aceito em: 23-04-2018

\begin{abstract}
The classical genetic improvement aims to select, mainly, cultivars with greater yield potentials; however, by associating the selection for disease resistance, it is possible to handle the management with cost reduction. The objective of this study was to evaluate the reaction of soybean genotypes to foliar diseases, and the agronomic characteristics of the soybean crop, with and without fungicide application. Two experiments were conducted concomitantly, in the same design and with the same managements, distinguishing with respect to the presence and absence of chemical treatment to control diseases. The experiments were conducted in Rio Verde, Goiás, in the 2015/2016 harvest, in a randomized complete block design with 31 soybean genotypes and three replicates. The plot consisted of 2 rows of $5 \mathrm{~m}$ in length, spaced $0.5 \mathrm{~m}$ apart. The following were evaluated: downy mildew severity, Asian rust, target spot, and end-of-cycle diseases (EOCD's), besides agronomic characteristics such as defoliation, thousand grain weight, and grain yield. For target spot and EOCD's, genotypes with lower susceptibility to diseases were observed. Regarding downy mildew and Asian rust, the genotypes have been shown to be susceptible, and chemical control was the most effective in the management of these pathogens. There was a significant interaction for thousand grain weight and grain yield, which implies that there is a distinct behavior of the genotypes regarding the presence and absence of diseases. The presence of diseases affected all the characteristics significantly, however, some genotypes stood out in both experiments, not presenting a significant reduction in grain yield when predisposed to the incidence of foliar diseases, consolidating effective control through genetic resistance.
\end{abstract}

Additional keywords: chemical control; genetic breeding; genetic resistance; Glycine max.

\section{Resumo}

O melhoramento genético clássico visa a selecionar, principalmente, cultivares com maiores potenciais produtivos; entretanto, associando a seleção para resistência a doenças, pode-se viabilizar o manejo com redução de custo. O objetivo deste estudo foi avaliar a reação de genótipos de soja a doenças foliares e as características agronômicas da cultura da soja, com e sem aplicação de fungicidas. Foram conduzidos dois experimentos concomitantemente, no mesmo delineamento e com os mesmos tratamentos, distinguindo com relação à presença $\mathrm{e}$ à ausência de manejo químico para controle de doenças. Os experimentos foram conduzidos em Rio Verde, Goiás, na safra de 2015/2016, no delineamento experimental de blocos ao acaso, com 31 genótipos de soja e três repetições. A parcela foi constituída de 2 linhas de $5 \mathrm{~m}$ de comprimento, espaçadas entre si por 0,5 m. Avaliaram--se a severidade de míldio, a ferrugem-asiática, a mancha-alvo e as doenças de final de ciclo (DFC's), além das características agronômicas, como desfolha, peso de mil grãos e produtividade de grãos. Para mancha-alvo e DFCs, observaram-se genótipos com menor suscetibilidade às doenças. Em relação a míldio e ferrugem asiática, os genótipos demonstraram ser suscetíveis, e o controle químico, mais eficaz no manejo destes patógenos. Ocorreu interação significativa para peso de mil grãos e produtividade de grãos, o que implica haver comportamento distinto dos genótipos entre presença e ausência de doenças. A presença de doenças afetou significativamente todas as características; todavia, alguns genótipos destacaram-se em ambos os experimentos, não apresentando redução significativa da produtividade de grãos quando predispostos à incidência de doenças foliares, consolidando o controle efetivo através da resistência genética.

Palavras-chave adicionais: controle químico; Glycine max; melhoramento genético; resistência genética. 


\section{Introduction}

The soybean crop [Glycine max (L.) Merrill] represents one of the main segments of the agribusiness sector in Brazil, being cultivated throughout the country. With a production of approximately 113 million tons, this oilseed reaches approximately $58 \%$ of the total area planted in Brazil (CONAB, 2017).

One of the major factors limiting the achievement of high yields in soybean crops is the presence of diseases. Among them, stand out foliar diseases caused by fungi, which directly affect the number of pods per plant and the grain weight, since they provide a reduction of the photosynthetically active area and cause the early senescence of leaves, shortening the crop cycle (Yorinori et al., 2005). In addition to Asian rust (Phakopsora pachyrhizi Sydow \& Sydow), other fungal diseases such as downy mildew (Peronospora manshurica (Naumov) Syd.), septoriosis (Septoria glycines Hemmi), Cercospora leaf blight (Cercospora kikuchii (Matsu. \& Tomoyasu)), and target spot (Corynespora cassiicola (Berky \& Curt) Wei) are important because their occurrence is more frequent, causing considerable economic damage (Amorin et al., 2016).

The disease control has required a combination of practices, associating the cultural, chemical, and genetic management, which aim to minimize yield losses, providing economic viability to the crop. Among the control methods, the chemical, through fungicides, has been the most used, since there is a reduction of the pathogen inoculum, of the sporulation suppression, and of the dispersion of spores in the field. Notwithstanding, the most effective, practical, and economical method of control is the use of varieties that are resistant or have some degree of resistance to diseases (Galli et al., 2007). Due to the variability of the pathogens, the development of resistant strains should be performed for each specific region, as this may be variable according to the edaphoclimatic conditions (Juliatti et al., 2003).

The objective of this work was to evaluate the reaction of soybean genotypes to foliar diseases, and their influence on the agronomic characteristics of the soybean crop, with and without fungicide application, in the region of Rio Verde, Goiás.

Two concurrent experiments were established, in the same design and with the same managements, distinguishing in relation to the presence and absence of chemical treatment for disease control, in the 2015/2016 harvest, in Rio Verde, Goiás (1746'56.32" S, 5059'53.26" W, 763 m altitude). According to Köppen-Geiger (1936), Rio Verde is classified as Aw, tropical climate with dry winter season (June to August). The soil in the area was classified as clayey $(48.1 \%$ clay, $36.4 \%$ sand, and $15.5 \%$ silt). Fertilization was carried out according to the crop requirements, after previous soil chemical analysis.

Both experiments were conducted in a randomized complete block design with 31 soybean gen- otypes and three replicates. Each plot consisted of 2 rows of $5 \mathrm{~m}$ in length, spaced $0.5 \mathrm{~m}$ apart. The 31 genotypes are from the breeding program of the company Caraíba Genética, being 30 experimental strains and one cultivar (CG 8166RR), which notably present variability in the reaction to main foliar diseases: CG121616R98rr, CG12-1616R2rr, CG12-1615R64rr, CG121538R18rr, CG56-4626C, CG07-1261B05, CG081443B01-01, CG08-1391B12-01, CG07-1257B02-01, CG08-1443B01-02, CG08-1391B12-02, CG071257B02-02, CG07-1310B102, CG08-1410B20, CG08-1394B02, CG07-1317B05, CG06-1010B09-01, CG07-1292B505, CG07-1262B101, CG08-1411B02, CG08-1396B02, CG07-1313B106, CG08-1400B785, CG07-1315B102, CG07-1297B574, CG56-7720C, CG06-1010B09-02, CG06-1020B05, CG08-1387B12, CG12-1539R3rr, and CG 8166RR. A row was sown between the plots with the soybean cultivar CG 8166RR, which is known to be more susceptible to foliar diseases, as a source of inoculum.

The sowing was done manually in previously opened furrows, which were fertilized with a sowingfertilizer machine used for no-tillage on November 14, 2015. In the experiment submitted to the chemical treatment for disease control, three applications of the fungicide trifloxystrobin + prothioconazole were performed in the doses of $70+60 \mathrm{~g}$ a.i. ha ${ }^{-1}$, respectively, with the addition of mineral oil (Aureo) at a dose of $0.25 \% \mathrm{v} / \mathrm{v}$. The first application was performed at the beginning of flowering (R1 stage); the second, at the R4 stage; and the third, at the R5.4 stage. The other cultural practices, such as pest and weed management, were carried out in both experiments, following the technical recommendations for the crop and according to the need verified in periodic surveys. In the complementation of weed control, a mechanical weeding was performed.

The diseases occurred by natural infection in the field and were evaluated weekly, based on notes made by two independent evaluators. Downy mildew severity was evaluated based on the diagrammatic scale of Kowata (2008). The evaluation of target spot severity was performed according to the diagrammatic scale of Soares (2009). In the evaluation of Asian rust severity, the diagrammatic scale of Canteri \& Godoy (2003) was used. Regarding end-of-cycle diseases (EOCD's), both for septoriosis and Cercospora leaf blight, the severities were evaluated based on the diagrammatic scale of Martins et al. (2004).

From the severity data, the area under the disease progress curve (AUDPC) for all diseases was calculated using the formula proposed by Shaner \& Finnley (1977): AUDPC $=\Sigma(\mathrm{yi}+\mathrm{yi}+1) / 2$ * $(\mathrm{ti}+1-\mathrm{ti})$, where yi and $y i+1$ are the severity values observed in two consecutive evaluations, and ti+1 - ti represents the interval between two evaluations.

The evaluations of the agronomic characteristics of the soybean strains were performed from the observation of the plot, namely: defoliation - evaluation of defoliation caused by infestation of foliar diseases, 
based on the diagrammatic scale of Hirano et. al (2010), performed at 15 days after the third application of the fungicide, for the two experiments; thousand grain weight - through counting and weighing, with the weight being corrected to $13 \%$ moisture; grain yield obtained from the harvest of the plants in the plot, and later tracking and weighing of the grains, with the values being converted to $\mathrm{kg} \mathrm{ha}^{-1}$ and corrected to $13 \%$ moisture.

The data were submitted to individual statistical analysis; identifying the homogeneity of residual variances by the Hartley test (Ramalho et al., 2005), joint variance analysis was used. For the effect of genotypes, the Scott-Knott means comparison test was used at $5 \%$ probability. All analyses were performed using the GENES software (Cruz, 2006).

\section{Results and discussions}

The influence of the chemical treatment with fungicides was significant in all variables, however, there was a significant interaction between genotypes and managements only for target spot and end-of-cycle diseases (EOCD's). The results suggest that the genotypes behaved non-coincidentally in the absence and presence of chemical treatment with fungicides, evidencing the most expressive influence of the chemical control for disease suppression in the genotypes that presented higher AUDPC means, that is, with higher levels of disease severity (Table 1). In general, for genotypes with lower mean AUDPC values in the untreated test, the reduction in severity levels with chemical control was not significant, highlighting the importance of the association of genetic resistance with other techniques for greater efficacy in reducing the severity of foliar diseases.

It was observed that in the test without fungicides, regarding target spot, 19 genotypes had significantly lower AUDPC than the others, with means varying between 6.0 (CG08-1443B01-01 and CG081396B02) and 30.0 (CG12-1615R64rr); the other 12 genotypes with higher AUDPC ranged between 34.5 (CG07-1297B574 and CG07-1297B574) and 66.0 (CG07-1292B505). Thus, the occurrence of genetic variability is suggested as to the reaction of the genotypes to target spot. For the test with fungicide application, the soybean genotypes did not differ significantly from each other, with AUDPC values varying from 3.2 to 22.4 (Table 1).

The influence of chemical treatment was evident in 9 genotypes, for which a significant difference was observed between the managements, with and without fungicide. The chemical control provided a reduction of $69.7 \%, 66.7 \%, 73.6 \%, 63.3 \%, 81.9 \%$, $73.0 \%, 76.3 \%, 61.4 \%$, and $79.7 \%$ in genotypes CG121538R18rr, CG07-1261B05, CG08-1410B20, CG071317B05, CG07-1292B05, CG07-1262B101, CG071313B106, CG07-1315B102, and CG56-7720C, respectively. It is possible to emphasize that the influence of the chemical control was observed in the gen- otypes that presented high AUDPC means, whereas in the genotypes with relatively low means of the infection of the pathogen, no significant reduction was observed with the fungicide application, which suggests a greater efficacy in reducing the severity of the disease, associating the use of genotypes that are more resistant to chemical control (Table 1).

Miguel-Wruck et al. (2011) identified soybean strains that were more resistant to target spot in the state of Mato Grosso; the cultivars Anta $82 \mathrm{RR}$, M-SOY $7908 \mathrm{RR}$, and BRS Valiosa RR behaved as resistant to target spot, presenting a severity lower than 3\%. According to the classification of resistance to target spot presented by Embrapa Soja (2014), only 4 cultivars are classified as resistant, and another 11 cultivars as moderately resistant. However, target spot resistant cultivars comprise less than $1 \%$ of the commercial cultivars, evidencing the importance of the chemical control of this disease.

In the end-of-cycle diseases evaluated in the experiment without treatment, there was a significant difference between the evaluated genotypes. Nineteen strains stood out with significantly lower means than the others, with AUDPC between 147.7 (CG12-1539R3rr) and 231.1 (CG56-4626C) (Table 1). The 12 genotypes with higher mean AUDPC values varied from 257.2 (CG07-1257B02-02) to 396.9 (CG12-1616R2rr). The soybean genotypes did not differ significantly from each other, with AUDPC values varying from 106.0 (CG12-1538R18rr) to 232.0 (CG07-1310B102). Analyzing the AUDPC results of the EOCD's in the experiment with fungicide application, the soybean genotypes did not differ significantly from each other, with AUDPC values ranging from 106.0 (CG12-1538R18rr) to 232.0 (CG07-1310B102). It should be noted that the chemical treatment provided a reduction in the severity of the pathogen so that it was not possible to observe significant variations due to the low mean AUDPC values obtained in all genotypes (Table 1).

The different reactions of the genotypes to end--of-cycle diseases were also observed by Rampazzo \& Blum (2014), when evaluating soybean cultivars in the presence of Septoria glycines, and by Kudo \& Blum (2011), when evaluating Cercospora foliar blight in 86 conventional and 30 transgenic genotypes.

Fifteen genotypes stood out, differing significantly between the different treatments, with disease reduction between 32.0\% (CG07-1310B102) and $60.7 \%$ (CG12-1615R64rr). It is noteworthy that these genotypes are among those with high AUDPC values. Notwithstanding, it was evidenced that some genotypes that did not differ significantly between the treatments, which demonstrated low AUDPC values in the experiment without fungicide application, may be associated with greater genetic resistance.

For downy mildew and Asian rust, a non-significant effect of the interaction genotype $x$ fungicide was observed, that is, the behavior of the genotypes 
was similar regardless of the treatment. It should be noted that, for Asian rust, all genotypes presented similar levels of severity, however, disease management with fungicide application provided a significant reduction in the AUDPC (Table 2).

Observing the AUDPC means for downy mildew, regardless of the treatment used, it was found that 6 strains (CG56-4626C, CG06-1020B05, CG081394B02, CG08-1410B20, CG07-1315B102, and CG08-1411B02) and the standard cultivar CG 8166RR were grouped with lower AUDPC, varying between
8.93 and 33.10. The strain CG12-1616R2rr had a higher AUDPC value, with a mean of 200.23 (Table 2). This shows that there is genetic variability regarding the reaction of the genotypes to this pathogen, being possible to distinguish between the evaluated ones, in which those with lower levels of severity can contribute to the management of this disease. The results confirm genetic variability for the reaction to this pathogen, which was also observed by Polizel et al. (2013), when evaluating the downy mildew AUDPC in soybean strains and cultivars.

Table 1 - Area under progression curve the target spot and end-of-cycle diseases (ECDs) in 31 soybean genotypes, without fungicide application (WF) and fungicide application (FA) and summary of variance analysis.

\begin{tabular}{|c|c|c|c|c|c|c|}
\hline \multirow{3}{*}{$\begin{array}{l}\text { Genotypes } \\
\text { CG12-1616R98rr }\end{array}$} & \multicolumn{4}{|c|}{ Target spot } & \multicolumn{2}{|c|}{ ECDs } \\
\hline & \multicolumn{2}{|c|}{ WF } & \multicolumn{2}{|c|}{ FA } & WF & \multirow{2}{*}{$\begin{array}{c}\text { FA } \\
155.8 \mathrm{aA}\end{array}$} \\
\hline & 35.7 & $\mathrm{bA}$ & 15.3 & $\mathrm{aA}$ & $301.5 \mathrm{bB}$ & \\
\hline CG12-1616R2rr & 28.5 & $\mathrm{aA}$ & 12.8 & $\mathrm{aA}$ & $396.9 \mathrm{bB}$ & $182.3 \mathrm{aA}$ \\
\hline CG12-1615R64rr & 30.0 & $\mathrm{aA}$ & 9.0 & $\mathrm{aA}$ & 308.4 bB & $121.1 \mathrm{aA}$ \\
\hline CG12-1538R18rr & 39.7 & $\mathrm{bB}$ & 12.0 & $\mathrm{aA}$ & $215.3 \mathrm{aB}$ & $106.0 \mathrm{aA}$ \\
\hline CG56-4626C & 19.5 & $\mathrm{aA}$ & 6.0 & $\mathrm{aA}$ & $231.1 \mathrm{aB}$ & $127.5 \mathrm{aA}$ \\
\hline CG07-1261B05 & 36.0 & $b B$ & 12.0 & $\mathrm{aA}$ & $284.0 \mathrm{bB}$ & $143.9 \mathrm{aA}$ \\
\hline CG08-1443B01-01 & 6.0 & $\mathrm{aA}$ & 10.5 & $\mathrm{aA}$ & 149.4 aA & $165.0 \mathrm{aA}$ \\
\hline CG08-1391B12-01 & 12.0 & $\mathrm{aA}$ & 18.0 & $\mathrm{aA}$ & $222.1 \mathrm{aA}$ & $211.6 \mathrm{aA}$ \\
\hline CG07-1257B02-01 & 22.5 & $\mathrm{aA}$ & 7.5 & $\mathrm{aA}$ & $285.1 \mathrm{bB}$ & $176.6 \mathrm{aA}$ \\
\hline CG08-1443B01-02 & 20.0 & $\mathrm{aA}$ & 9.3 & $\mathrm{aA}$ & $167.8 \mathrm{aA}$ & $161.7 \mathrm{aA}$ \\
\hline CG08-1391B12-02 & 15.0 & $\mathrm{aA}$ & 10.5 & $\mathrm{aA}$ & $192.5 \mathrm{aA}$ & $161.7 \mathrm{aA}$ \\
\hline CG07-1257B02-02 & 16.5 & $\mathrm{aA}$ & 6.8 & $\mathrm{aA}$ & $257.2 \mathrm{bB}$ & $163.3 \mathrm{aA}$ \\
\hline CG07-1310B102 & 24.7 & $\mathrm{aA}$ & 22.4 & $\mathrm{aA}$ & $341.3 \mathrm{bB}$ & $232.0 \mathrm{aA}$ \\
\hline CG08-1410B20 & 41.5 & $\mathrm{bB}$ & 11.0 & $\mathrm{aA}$ & $216.4 \mathrm{aA}$ & $145.0 \mathrm{aA}$ \\
\hline CG08-1394B02 & 12.3 & $\mathrm{aA}$ & 7.5 & $\mathrm{aA}$ & $175.8 \mathrm{aA}$ & $172.7 \mathrm{aA}$ \\
\hline CG07-1317B05 & 52.7 & $\mathrm{bB}$ & 19.3 & $\mathrm{aA}$ & $311.0 \mathrm{bB}$ & $167.3 \mathrm{aA}$ \\
\hline CG06-1010B09-01 & 21.5 & $\mathrm{aA}$ & 6.0 & $\mathrm{aA}$ & $155.5 \mathrm{aA}$ & $118.1 \mathrm{aA}$ \\
\hline CG07-1292B505 & 66.0 & bB & 11.9 & $\mathrm{aA}$ & $230.6 \mathrm{aB}$ & $138.2 \mathrm{aA}$ \\
\hline CG07-1262B101 & 35.2 & $\mathrm{bB}$ & 9.5 & $\mathrm{aA}$ & $208.0 \mathrm{aA}$ & $152.3 \mathrm{aA}$ \\
\hline CG08-1411B02 & 20.0 & $\mathrm{aA}$ & 11.3 & $\mathrm{aA}$ & $217.7 \mathrm{aA}$ & $144.7 \mathrm{aA}$ \\
\hline CG08-1396B02 & 6.0 & $\mathrm{aA}$ & 7.5 & $\mathrm{aA}$ & $221.8 \mathrm{aA}$ & $166.6 \mathrm{aA}$ \\
\hline CG07-1313B106 & 47.5 & $\mathrm{bB}$ & 11.3 & $\mathrm{aA}$ & 292.7 bB & $194.9 \mathrm{aA}$ \\
\hline CG08-1400B785 & 10.5 & $\mathrm{aA}$ & 7.5 & $\mathrm{aA}$ & $225.3 \mathrm{aA}$ & $162.8 \mathrm{aA}$ \\
\hline CG07-1315B102 & 52.5 & $\mathrm{bB}$ & 20.3 & $\mathrm{aA}$ & $310.8 \mathrm{bB}$ & $208.9 \mathrm{aA}$ \\
\hline CG07-1297B574 & 34.5 & bA & 13.8 & $\mathrm{aA}$ & $165.8 \mathrm{aA}$ & $167.8 \mathrm{aA}$ \\
\hline CG56-7720C & 48.0 & $\mathrm{bB}$ & 9.8 & $\mathrm{aA}$ & $222.7 \mathrm{aA}$ & $159.1 \mathrm{aA}$ \\
\hline CG06-1010B09-02 & 22.5 & $\mathrm{aA}$ & 13.5 & $\mathrm{aA}$ & $172.6 \mathrm{aA}$ & $127.2 \mathrm{aA}$ \\
\hline CG06-1020B05 & 34.5 & bA & 18.8 & $\mathrm{aA}$ & 284.8 bB & $166.5 \mathrm{aA}$ \\
\hline CG08-1387B12 & 9.0 & $\mathrm{aA}$ & 6.8 & $\mathrm{aA}$ & $258.9 \mathrm{bB}$ & $168.4 \mathrm{aA}$ \\
\hline CG12-1539R3rr & 20.0 & $\mathrm{aA}$ & 9.8 & $\mathrm{aA}$ & $147.7 \mathrm{aA}$ & $137.1 \mathrm{aA}$ \\
\hline CG 8166RR & 12.0 & $\mathrm{aA}$ & 3.2 & $\mathrm{aA}$ & $227.6 \mathrm{aA}$ & $155.8 \mathrm{aA}$ \\
\hline Mean & 27.5 & & 11.31 & & 238.66 & 160.1 \\
\hline Causes of variation & \multicolumn{6}{|c|}{ Mean squares } \\
\hline Genotype (G) & \multicolumn{4}{|c|}{$483.67^{* *}$} & \multicolumn{2}{|c|}{8943.38 ** } \\
\hline Management (M) & \multicolumn{4}{|c|}{$12169.46^{* *}$} & \multicolumn{2}{|c|}{$287317.44^{* *}$} \\
\hline $\mathrm{G} \times \mathrm{M}$ & \multicolumn{4}{|c|}{$288.17^{*}$} & \multicolumn{2}{|c|}{4584.20 * } \\
\hline
\end{tabular}

Means of genotypes followed by the same lowercase letters and means of fungicide management with upper case letters do not differ significantly by the Scott Knott test $(P>0,05 \%)$. *, ** significant at $5 \%$ and $1 \%$ of probability, respectively, by the mean squares. ${ }^{\text {ns }}$ not significant. 
Table 2 - Area under the progression curve of mildew and Asian rust in 31 soybean genotypes without fungicide application (WF) and with application of fungicide (FA) of fungicide and summary of variance analysis.

\begin{tabular}{|c|c|c|c|c|c|c|}
\hline \multirow{2}{*}{ Genotypes } & \multicolumn{2}{|c|}{ Mildew } & \multirow{2}{*}{ Mean } & \multicolumn{2}{|c|}{ Asian rust } & \multirow{2}{*}{ Mean } \\
\hline & WF & FA & & WF & FA & \\
\hline CG12-1616R98rr & 93.3 & 67.8 & $80.5 \mathrm{c}$ & 380.0 & 17.3 & $198.6 \mathrm{a}$ \\
\hline CG12-1616R2rr & 22.0 & 178.5 & $200.2 \mathrm{e}$ & 406.0 & 28.0 & $217.0 \mathrm{a}$ \\
\hline CG12-1615R64rr & 62.8 & 45.3 & $54.0 \mathrm{~b}$ & 271.6 & 15.0 & $143.3 \mathrm{a}$ \\
\hline CG12-1538R18rr & 45.3 & 35.8 & $40.5 \mathrm{~b}$ & 389.0 & 16.6 & $202.8 \mathrm{a}$ \\
\hline CG56-4626C & 12.5 & 5.3 & 8.9 a & 544.3 & 29.3 & $286.8 \mathrm{a}$ \\
\hline CG07-1261B05 & 40.5 & 58.9 & $49.7 \mathrm{~b}$ & 396.6 & 19.6 & $208.1 \mathrm{a}$ \\
\hline CG08-1443B01-01 & 41.0 & 52.0 & $46.5 \mathrm{~b}$ & 337.0 & 25.0 & $181.0 \mathrm{a}$ \\
\hline CG08-1391B12-01 & 81.3 & 49.0 & $65.1 \mathrm{~b}$ & 299.3 & 29.3 & $164.3 \mathrm{a}$ \\
\hline CG07-1257B02-01 & 121.0 & 82.1 & $102.0 \mathrm{c}$ & 351.0 & 14.6 & $182.8 \mathrm{a}$ \\
\hline CG08-1443B01-02 & 59.0 & 59.4 & $59.2 \mathrm{~b}$ & 323.3 & 23.6 & $173.5 \mathrm{a}$ \\
\hline CG08-1391B12-02 & 93.0 & 94.7 & $93.8 \mathrm{c}$ & 322.0 & 43.3 & $182.6 \mathrm{a}$ \\
\hline CG07-1257B02-02 & 102.4 & 104.3 & $103.3 \mathrm{c}$ & 242.3 & 13.6 & $128.0 \mathrm{a}$ \\
\hline CG07-1310B102 & 118.1 & 86.7 & $102.4 \mathrm{c}$ & 427.3 & 28.6 & $228.0 \mathrm{a}$ \\
\hline CG08-1410B20 & 35.5 & 23.3 & 29.4 a & 392.0 & 31.3 & $211.6 a$ \\
\hline CG08-1394B02 & 27.93 & 21.7 & $24.8 \mathrm{a}$ & 352.6 & 29.0 & $190.8 \mathrm{a}$ \\
\hline CG07-1317B05 & 188.0 & 104.3 & $146.1 \mathrm{~d}$ & 360.0 & 31.6 & $195.8 \mathrm{a}$ \\
\hline CG06-1010B09-01 & 82.0 & 43.6 & $62.7 \mathrm{~b}$ & 397.0 & 17.3 & $207.1 \mathrm{a}$ \\
\hline CG07-1292B505 & 89.2 & 49.4 & $69.3 \mathrm{~b}$ & 403.3 & 19.6 & $211.5 \mathrm{a}$ \\
\hline CG07-1262B101 & 69.5 & 26.7 & $48.1 \mathrm{~b}$ & 442.0 & 19.3 & $230.6 a$ \\
\hline CG08-1411B02 & 37.6 & 28.6 & $33.1 \mathrm{a}$ & 335.3 & 66.3 & $200.8 a$ \\
\hline CG08-1396B02 & 113.4 & 76.2 & $94.8 \mathrm{c}$ & 428.6 & 30.3 & $229.5 \mathrm{a}$ \\
\hline CG07-1313B106 & 84.7 & 86.2 & $85.4 \mathrm{c}$ & 373.0 & 35.6 & $204.3 \mathrm{a}$ \\
\hline CG08-1400B785 & 63.8 & 58.3 & $61.0 \mathrm{~b}$ & 303.6 & 20.0 & $161.8 \mathrm{a}$ \\
\hline CG07-1315B102 & 30.9 & 30.9 & 30.9 a & 463.0 & 60.6 & $261.8 a$ \\
\hline CG07-1297B574 & 80.0 & 45.0 & $62.5 \mathrm{~b}$ & 276.3 & 113.3 & $194.8 \mathrm{a}$ \\
\hline CG56-7720C & 42.0 & 43.2 & $42.6 \mathrm{~b}$ & 380.0 & 57.6 & $218.8 a$ \\
\hline CG06-1010B09-02 & 71.7 & 44.3 & $58.0 \mathrm{~b}$ & 274.6 & 13.6 & $144.1 \mathrm{a}$ \\
\hline CG06-1020B05 & 21.0 & 23.2 & $22.1 \mathrm{a}$ & 440.0 & 37.0 & $238.5 \mathrm{a}$ \\
\hline CG08-1387B12 & 131.9 & 97.7 & $114.8 \mathrm{c}$ & 264.3 & 41.6 & $153.0 \mathrm{a}$ \\
\hline CG12-1539R3rr & 106.5 & 71.6 & $89.0 \mathrm{c}$ & 309.6 & 28.0 & $168.8 \mathrm{a}$ \\
\hline CG 8166RR & 14.0 & 6.3 & $10.1 \mathrm{a}$ & 254.3 & 17.3 & $135.8 \mathrm{a}$ \\
\hline Mean & $76.8 \mathrm{~B}$ & $58.1 \mathrm{~A}$ & & $359.3 \mathrm{~B}$ & $31.4 \mathrm{~A}$ & \\
\hline Causes of variation & \multicolumn{6}{|c|}{ Mean Squares } \\
\hline Genotype (G) & \multicolumn{2}{|c|}{9923.01 ** } & \multicolumn{4}{|c|}{7833.42 ns } \\
\hline Management (M) & \multicolumn{2}{|c|}{$16369.23^{* *}$} & \multicolumn{4}{|c|}{5000360.26 ** } \\
\hline$G \times M$ & \multicolumn{2}{|c|}{706.87 ns } & \multicolumn{4}{|c|}{$8031.41 \mathrm{~ns}$} \\
\hline
\end{tabular}

Means of genotypes followed by the same lowercase letters and means of fungicide management with upper case letters do not differ significantly by the Scott Knott test $(\mathrm{P}>0,05 \%) .{ }^{*}$, ** significant at $5 \%$ and $1 \%$ of probability, respectively, by the mean squares. ${ }^{\text {ns }}$ not significant. 
In general, the results suggest that there is a significant effect of the fungicide application regardless of the genotype, which led to a reduction in the mean AUDPC of downy mildew from 76.8 in the experiment without fungicide application to 58.1 in the experiment with fungicide application. The low efficacy of the fungicide trifloxystrobin (EQls - external quinone inhibitors) + prothioconazole (DMls - demethylation inhibitors) should be highlighted, of only $24.4 \%$ for downy mildew control. It is important to note that this fungicide is not recommended for the control of this disease; hence, it is necessary to seek other alternatives of active ingredients for the management.

Regarding the AUDPC for Asian rust, the 31 soybean genotypes did not differ significantly from each other, evidencing the limitation of obtaining genotypes resistant to this disease. The AUDPC values varied from 128.0 (CG07-1257B02-02) to 286.83 (CG56-4626C); however, because there was no significant difference between the genotypes, it is suggested that there is uniformity in their reaction to Asian rust (Table 2). Nonetheless, the reaction of the genotypes to Asian rust showed similar behavior, that is, coincidence, with and without fungicide application.

Fungicide control provided a significant reduction in the AUDPC for Asian rust, from 359.35 to 31.43, representing a $91.25 \%$ reduction in the severity of this pathogen. This suggests that among the evaluated genotypes, the most effective method in the management of this disease is the application of fungicides, and that there was no contribution of the genetic aspect in reducing the severity. On the other hand, Azevedo (2007), when evaluating 50 soybean genotypes in the Cerrado region, observed a significant variation in the reaction to this pathogen. The cultivars Emgopa 313 and Monsoy 8211 showed a lower average number of pustules per $\mathrm{cm}^{2}$, lower severity, and lower values of area under the disease progression curve.

Regarding the agronomic characteristics, 13 genotypes stood out in the defoliation percentage, with averages varying between 53.3\% (CG 8166RR) and $71.7 \%$ (CG07-1261B05) (Table 3). In this way, it is possible to distinguish some genotypes with a greater capacity to tolerate the pathogen infection, or even providing the maintenance of a larger leaf area due to their greater genetic resistance, which can contribute to an increase in grain yield. It is observed that there was a significant reduction in the defoliation percentage, from $83.1 \%$ in the test without fungicide application to $64.2 \%$ in the test with fungicide application. In general, the phytosanitary management influenced positively, regardless of the genotype, in the maintenance of leaf area until the physiological maturation stage. Defoliation caused by foliar diseases affects the photosynthetic activity of the plant, causing direct losses in grain yield.

It can be observed that in the experiment with- out fungicide application, 8 genotypes presented a thousand grain weight significantly higher than the others, with averages varying between $149.3 \mathrm{~g}$ (CG071292B505) and $161.7 \mathrm{~g}$ (CG07-1261B05). In the test in which fungicide application was carried out, 7 genotypes stood out in relation to the others, with thousand grain weight averages between $160.6 \mathrm{~g}$ (CG081394B02) and $173.6 \mathrm{~g}$ (CG07-1261B05). It is noteworthy that only 10 genotypes presented a significant increase in the thousand grain weight with the chemical control of the diseases, highlighting that most of these genotypes presented high mean AUDPC values (Table 3).

In the test without fungicide application, strains CG08-1391B12-02 and CG07-1257B02-02 stood out, showing higher grain yield means, with values of 3600 and $3808 \mathrm{~kg} \mathrm{ha}^{-1}$, respectively (Table 3 ). It should be taken into account that these strains showed lower AUDPC means, since even with disease incidence, they presented high grain yield. The genotype CG081391B12-02 is highlighted, also with lower defoliation averages, which may have contributed to the expression of its genetic potential. Moreover, the strain CG071313B106 stood out in the test with fungicide application, showing higher grain yield, yielding an average of $4291 \mathrm{~kg} \mathrm{ha}^{-1}$, followed by 16 genotypes with yields between 3330 and $3885 \mathrm{~kg} \mathrm{ha}^{-1}$. This genotype showed low grain yield in the test without fungicide application, however, in the absence of foliar diseases, it can express its genetic potential. It is important to highlight the genotype CG08-1391B12-02 that, in general, stood out in both tests, suggesting that, when using genetic resistance in disease management, it is possible to reduce costs with phytosanitary control, applying fungicides only when necessary.

Regarding the influence in the evaluated genotypes, with and without fungicide application, it was verified that 17 genotypes presented a significant difference between treatments, with an increase in grain yield when submitted to disease control, ranging from $666 \mathrm{~kg} \mathrm{ha}^{-1}$ (CG07-1315B102) to $1838 \mathrm{~kg} \mathrm{ha}^{-1}$ (CG071313B106). The other strains showed similar grain yield, both in the test with and without chemical treatment, which can be explained by their tolerance to pathogen infection.

Carniel et al. (2014) evaluated the reaction of four RR soybean cultivars to EOCD's, with and without fungicide application, and found that one cultivar showed similar yield with and without fungicide, and that the use of soybean cultivars with high resistance to EOCD's allows to reduce the dependence of fungicides to obtain high grain yields. Finoto et al. (2011) point out that the control of EOCD's provided an increase in grain yield, with the best results being obtained with fungicide application at the R5 or R5.5 stage. Foliar diseases are known to decrease the leaf life span, reducing the net photosynthesis and grain yield of the soybean crop (Godoy \& Canteri, 2004). 
Table 3 - Defoliation percentage (DEF), thousand grain weigth (TGW) and grain yield (YIELD) of 31 soybean genotypes without fungicide application (WF) and fungicide application (FA) and summary of variance analysis.

\begin{tabular}{|c|c|c|c|c|c|c|c|c|c|c|}
\hline \multirow{3}{*}{$\begin{array}{l}\text { Genotypes } \\
\text { CG12-1616R98rr }\end{array}$} & \multicolumn{2}{|c|}{ DEF (\%) } & \multirow{2}{*}{ Mean } & \multicolumn{3}{|c|}{ TGW (g) } & \multicolumn{4}{|c|}{ YIELD $\left(\mathrm{kg} \mathrm{ha}^{-1}\right)$} \\
\hline & WF & FA & & \multicolumn{2}{|c|}{ WF } & \multirow{2}{*}{$\frac{F A}{161.6 \mathrm{aA}}$} & \multicolumn{2}{|c|}{ WF } & \multicolumn{2}{|c|}{ FA } \\
\hline & 91.7 & 90.0 & $90.8 \mathrm{~b}$ & 157.7 & $\mathrm{aA}$ & & 2612 & $c A$ & 3131 & $c A$ \\
\hline CG12-1616R2rr & 80.0 & 88.3 & $84.2 \mathrm{~b}$ & 160.9 & $\mathrm{aA}$ & 163.6 aA & 2688 & $c A$ & 3138 & $c A$ \\
\hline CG12-1615R64rr & 96.7 & 85.0 & $90.8 \mathrm{~b}$ & 143.2 & $\mathrm{bA}$ & $143.9 \mathrm{bA}$ & 2772 & $\mathrm{cB}$ & 3582 & bA \\
\hline CG12-1538R18rr & 71.7 & 53.3 & $62.5 \mathrm{a}$ & 136.5 & $\mathrm{bA}$ & $135.5 \mathrm{cA}$ & 2662 & $c A$ & 2973 & $c A$ \\
\hline CG56-4626C & 98.3 & 55.0 & $76.7 \mathrm{~b}$ & 131.1 & $\mathrm{cB}$ & $145.6 \mathrm{bA}$ & 2417 & $\mathrm{cB}$ & 3189 & $c A$ \\
\hline CG07-1261B05 & 80.0 & 63.3 & $71.7 \mathrm{a}$ & 161.7 & $\mathrm{aB}$ & $173.6 \mathrm{aA}$ & 2906 & $\mathrm{bA}$ & 2988 & $c A$ \\
\hline CG08-1443B01-01 & 78.3 & 43.3 & $60.8 \mathrm{a}$ & 106.4 & $\mathrm{~dB}$ & $125.0 \mathrm{dA}$ & 2213 & $d A$ & 3858 & bB \\
\hline CG08-1391B12-01 & 86.7 & 70.0 & $78.3 \mathrm{~b}$ & 128.4 & $\mathrm{cB}$ & $147.7 \mathrm{bA}$ & 2596 & $c A$ & 3110 & $c A$ \\
\hline CG07-1257B02-01 & 93.3 & 75.0 & $84.2 \mathrm{~b}$ & 150.5 & $\mathrm{aA}$ & $147.8 \mathrm{bA}$ & 2926 & $\mathrm{bA}$ & 3330 & bA \\
\hline CG08-1443B01-02 & 70.0 & 53.3 & $61.7 \mathrm{a}$ & 116.6 & $\mathrm{dA}$ & $117.0 \mathrm{dA}$ & 2212 & $\mathrm{~dB}$ & 3655 & bA \\
\hline CG08-1391B12-02 & 63.3 & 68.3 & $65.8 \mathrm{a}$ & 141.1 & $\mathrm{bA}$ & $148.0 \mathrm{bA}$ & 3808 & $\mathrm{aA}$ & 3805 & bA \\
\hline CG07-1257B02-02 & 88.3 & 73.3 & $80.8 \mathrm{~b}$ & 153.6 & $\mathrm{aA}$ & $149.8 \mathrm{bA}$ & 3600 & $\mathrm{aA}$ & 3183 & $c A$ \\
\hline CG07-1310B102 & 96.7 & 80.0 & $88.3 \mathrm{~b}$ & 123.1 & $d A$ & $128.1 \mathrm{cA}$ & 3024 & $\mathrm{bA}$ & 2825 & $c A$ \\
\hline CG08-1410B20 & 80.0 & 85.0 & $82.5 \mathrm{~b}$ & 127.6 & $\mathrm{cA}$ & $131.0 \mathrm{cA}$ & 2071 & $d A$ & 2037 & $d A$ \\
\hline CG08-1394B02 & 88.3 & 68.3 & $78.3 \mathrm{~b}$ & 139.9 & $\mathrm{bB}$ & $160.6 \mathrm{aA}$ & 2586 & $\mathrm{cB}$ & 3786 & bA \\
\hline CG07-1317B05 & 96.7 & 76.7 & $86.7 \mathrm{~b}$ & 152.9 & $\mathrm{aB}$ & $166.9 \mathrm{aA}$ & 2469 & $\mathrm{cB}$ & 3824 & bA \\
\hline CG06-1010B09-01 & 65.0 & 43.3 & $54.2 \mathrm{a}$ & 98.4 & $\mathrm{eA}$ & 106.7 eA & 2744 & $\mathrm{cB}$ & 3463 & bA \\
\hline CG07-1292B505 & 93.3 & 70.0 & $81.7 \mathrm{~b}$ & 149.3 & $\mathrm{aA}$ & $144.3 \mathrm{bA}$ & 2688 & $\mathrm{cB}$ & 3435 & bA \\
\hline CG07-1262B101 & 85.0 & 46.7 & $65.8 \mathrm{a}$ & 144.6 & $\mathrm{bA}$ & $133.8 \mathrm{cB}$ & 2715 & $\mathrm{cA}$ & 3164 & $c A$ \\
\hline CG08-1411B02 & 88.3 & 66.7 & $77.5 \mathrm{~b}$ & 156.2 & $\mathrm{aA}$ & $155.3 \mathrm{bA}$ & 2115 & $\mathrm{~dB}$ & 3209 & $c A$ \\
\hline CG08-1396B02 & 91.7 & 63.3 & $77.5 \mathrm{~b}$ & 155.3 & $\mathrm{aB}$ & $170.4 \mathrm{aA}$ & 2907 & $\mathrm{bB}$ & 3885 & bA \\
\hline CG07-1313B106 & 90.0 & 76.7 & $83.3 \mathrm{~b}$ & 144.0 & $\mathrm{bA}$ & $139.9 \mathrm{bA}$ & 2453 & $\mathrm{cB}$ & 4291 & $\mathrm{aA}$ \\
\hline CG08-1400B785 & 90.0 & 73.3 & $81.7 \mathrm{~b}$ & 126.1 & $\mathrm{cA}$ & $130.1 \mathrm{cA}$ & 2710 & $\mathrm{cB}$ & 3499 & bA \\
\hline CG07-1315B102 & 88.3 & 71.7 & $80.0 \mathrm{~b}$ & 134.1 & $\mathrm{cA}$ & $142.9 \mathrm{bA}$ & 2563 & $\mathrm{cB}$ & 3230 & $c A$ \\
\hline CG07-1297B574 & 63.3 & 46.7 & $55.0 \mathrm{a}$ & 102.3 & $\mathrm{eA}$ & $103.3 \mathrm{eA}$ & 3019 & $\mathrm{bB}$ & 3814 & bA \\
\hline CG56-7720C & 76.7 & 60.0 & $68.3 \mathrm{a}$ & 116.7 & $\mathrm{~dB}$ & $132.1 \mathrm{cA}$ & 3088 & $\mathrm{bA}$ & 3237 & $c A$ \\
\hline CG06-1010B09-02 & 66.7 & 40.0 & $53.3 \mathrm{a}$ & 97.4 & $\mathrm{eA}$ & $102.0 \mathrm{eA}$ & 2637 & $\mathrm{cB}$ & 3807 & bA \\
\hline CG06-1020B05 & 78.3 & 63.3 & $70.8 \mathrm{a}$ & 131.1 & $\mathrm{cA}$ & $131.8 \mathrm{cA}$ & 3228 & $\mathrm{bA}$ & 3743 & bA \\
\hline CG08-1387B12 & 90.0 & 61.7 & $75.8 \mathrm{~b}$ & 110.8 & $\mathrm{dA}$ & $117.8 \mathrm{dA}$ & 2284 & $\mathrm{~dB}$ & 3463 & bA \\
\hline CG12-1539R3rr & 75.0 & 46.7 & $60.8 \mathrm{a}$ & 85.8 & $\mathrm{fB}$ & $98.0 \mathrm{eA}$ & 1513 & eA & 1856 & $d A$ \\
\hline CG 8166RR & 73.3 & 33.3 & $53.3 \mathrm{a}$ & 133.0 & $\mathrm{cB}$ & $165.0 \mathrm{aA}$ & 2767 & $\mathrm{cB}$ & 3442 & bA \\
\hline Mean & 83.13 & 64.21 & & 132.8 & & 139.3 & 2677 & & 3353 & \\
\hline Causes of variation & \multicolumn{10}{|c|}{ Mean squares } \\
\hline Genotype (G) & \multicolumn{3}{|c|}{797.69 ** } & \multicolumn{3}{|c|}{$2427.68^{* *}$} & \multicolumn{4}{|c|}{$978548^{* *}$} \\
\hline Management (M) & \multicolumn{3}{|c|}{$16465.05^{* *}$} & \multicolumn{3}{|c|}{$19991.37^{* *}$} & \multicolumn{4}{|c|}{22400168 ** } \\
\hline$G \times M$ & \multicolumn{3}{|c|}{$218.94 \mathrm{~ns}$} & \multicolumn{3}{|c|}{$126.35^{* *}$} & \multicolumn{4}{|c|}{$504026^{* *}$} \\
\hline
\end{tabular}

Means of genotypes followed by the same lowercase letters and means of fungicide management with upper case letters do not differ significantly by the Scott Knott test $(\mathrm{P}>0,05 \%) .{ }^{*},{ }^{* *}$ significant at $5 \%$ and $1 \%$ of probability, respectively, by the mean squares. ${ }^{\text {ns }}$ not significant. 


\section{Conclusion}

There was variability in the reaction of genotypes to target spot, EOCD's, and downy mildew. Regarding downy mildew, fungicide control showed low efficacy, but genotypes with higher resistance to this disease were observed. Regarding Asian rust, the genotypes did not differ significantly from each other, however, the control with fungicide application was efficient.

The association of chemical control with genotypes that presented lower severity in the evaluated diseases is effective in phytosanitary management. The use of genotypes with greater resistance to foliar diseases, associated with fungicide control, provided an increase in yield in the soybean crop.

\section{References}

Amorin L, Rezende Jam, Bergamin Filho A, Camargo Lea (2016) Manual de Fitopatologia. Doenças das Plantas Cultivadas. Ceres 5(2):820.

Azevedo Las, Juliatti FC, Barreto M (2007) Resistência de Genótipos de Soja à Phakopsora pachyrhizi. Summa Phytopathologica 33(3):252-257.

Canteri MG, Godoy CV (2003) Escala diagramática para avaliação da severidade da ferrugem da soja. Summa Phytopathologica 29(1):89.

Carniel LA, Menosso R, Balbinot Junior AA (2014) Reação de cultivares de soja às doenças de final de ciclo com e sem aplicação de fungicidas. Unoesc \& Ciência 5(1):83-90.

CONAB (2017) Companhia nacional de abastecimento. Acompanhamento da safra brasileira de grãos: safra 2016/2017. Disponível em: <http://www. conab.gov.br/safras.asp>. Acesso em: 15 maio 2017.

Cruz CD (2006) Programa Genes: Estatística Experimental e Matrizes. 1. ed. Viçosa: UFV, 2006, $385 p$.

Embrapa (2014) Empresa brasileira de pesquisa agropecuária. Tecnologias de produção de soja: região central do Brasil. Londrina: Embrapa Soja. 265p.

Finoto EV, Carrega WC, Sediyama T, Albuquerque JAA, Cecon PR, Reis MS (2011) Efeito da aplicação de fungicida sobre caracteres agronômicos e severidade das doenças de final de ciclo na cultura da soja. Revista Agro@mbiente On-line 5(1):44-49.

Galli JA, Panizzi RC, Vieira RD (2007) Resistência de variedades de soja à morte de plântulas causada por Colletotrichum truncatum. Arquivo Instituto Biológico 74(2):163-165.
Godoy C, Canteri M (2004) Efeito da severidade de oídio e crestamento foliar de Cercospora na produtividade da cultura da soja. Fitopatologia Brasileira 29(1):526-531.

Hirano, M; Hikishima, M; Silva, A.. Xavier, SA; Canteri, MG (2010) Validação de escala diagramática para estimativa de desfolha provocada pela ferrugem asiática em soja. Summa phytopathologica 36(3):248-250.

Juliatti FC, Borges EM, Passos RR, Caldeira Júnior JC, JULIATTI FC, BRANDÃO AM (2003) Doenças da soja. Cultivar 47(1):3-14.

Kowata LS, May-de-mio LL, Dalla PRIA M, Santos HAA (2008) Escala diagramática para avaliar severidade de míldio na soja. Scientia Agraria 9(1):105-110.

Kudo AS, Blum LEB (2011) Reação de genótipos de soja ao crestamento foliar de Cercospora. Bragantia 70(2):397-401.

Martins MC, Guerzoni RA, Câmara GMS, Mattiazzi P, Lourenço SA, Amorim L (2004) Escala diagramática para quantificação do complexo de doenças foliares de final de ciclo em soja. Fitopatologia Brasileira 29( 2):179-184.

Miguel-wruck DS, Paes JM, Zito RK, Wruck FJ, Damasceno G, Moulin MC (2011) Seleção de linhagens de soja quanto à resistência de Corynespora cassiicola safras 2009/2010. In: Reunião de pesquisa de soja da região central do Brasil, 32(1)120-122.

Polizel AC, Juliatti FC, Hamawaki OT, Silva EMB (2013) Reação de genótipos de soja de ciclo semiprecoce e médio quanto à severidade de manchas foliares. Bioscience Journal 29(5):1231-1242.

Ramalho MAP, Ferreira DF, Oliveira AC (2005) Experimentação em genética e melhoramento de plantas. UFLA. 322p.

Rampazzo LS, Blum LEB (2014) Reação de cultivares de soja à mancha parda sob diferentes técnicas de manejo. Revista Caatinga 27(3):115-123.

Shaner GE, Finnley RF (1977) The effects of nitrogen fertilization on the expression of slow-mildewing in wheat. Phytopathology 70(1):1183-1186.

Soares RM, Godoy CV, Oliveira MCN (2009) Escala diagramática para avaliação da severidade da mancha alvo da soja. Tropical plant Pathology 34(5):333-338.

Yorinori JT, Paiva WM, Frederick RD, Costamilan LM, Bertagnolli PF, Hartman GE, Godoy CV, Nunes Junior $J$ (2005) Epidemics of soybean rust (Phakopsora pachyrhizi) in Brazil and Paraguay from 2001 to 2003. Plant Disease 89(1):675-677. 